\title{
Apoptosis and survivability of human dental pulp cells under exposure to Bis-GMA
}

\author{
Junya YANO'1, Chiaki KITAMURA', Tatsuji NISHIHARA², Masayuki TOKUDA ${ }^{3}$, Ayako WASHIO', Ker-Kong CHEN", \\ Masamichi TERASHITA ${ }^{5}$ \\ 1- DDS, PhD, Division of Pulp Biology, Operative Dentistry, and Endodontics, Department of Cariology and Periodontology, Kyushu Dental College, Japan. \\ 2- DDS, PhD, Division of Infections and Molecular Biology, Department of Health Promotion, Kyushu Dental College, Japan. \\ 3- DDS, PhD, Department of Restorative Dentistry and Endodontology, Kagoshima University Graduate School of Medical and Dental Sciences, Japan. \\ 4- DDS, PhD, Department of Conservative Dentistry, Kaohsiung Medical University Hospital and College of Dental Medicine, Kaohsiung Medical University, \\ Kaohsiung, Taiwan. \\ 5- DDS, PhD, Division of Comprehensive Dentistry, Department of Clinical Communication Practice, Kyushu Dental College, Japan.
}

Corresponding address: Chiaki Kitamura, DDS, PhD - Division of Pulp Biology, Operative Dentistry and Endodontics, Department of Cariology and Periodontology, Kyushu Dental College, 2-6-1 - Manazuru - Kokurakita - Kitakyushu - 803-8580 - Japan - Phone: 81-93-582-1131 - Fax: 81-93-581-5399 e-mail: chi-aki-k@kyu-dent.ac.jp

Received: June 19, 2009 - Modification: March 19, 2010 - Accepted: March 27, 2010

\section{ABSTRACT}

\begin{abstract}
bjective: In the present study, we examined whether 2, 2-bis [4-(2-hydroxy-3methacryloxypropoxy) phenyl] propane (Bis-GMA) has effects on LSC2 cells, human dental pulp cell line. Material and Methods: The viability, cell cycle, and morphology of LSC2 cells were analyzed after exposure to several different concentrations of Bis-GMA. The recovery of viability of Bis-GMA exposed cells was also analyzed in the condition without Bis-GMA. Further, penetration of Bis-GMA to dentin disc was examined using isocratic high-performance liquid chromatography. Results: There was a concentration-dependent decrease in cell proliferation and an increase in cell number in the sub-G1 population after exposure to Bis-GMA. Furthermore, the cells showed typical characteristics of apoptotic cells after the exposure to high concentration of Bis-GMA. In contrast, cells exposed to lower concentrations of Bis-GMA recovered their viability after being cultured without Bis-GMA. We also found that Bis-GMA is capable of penetrating 1-mm-thick dentin discs, though the penetrated concentration was lower than that showing cytotoxicity. Conclusion: These results suggest that Bis-GMA has cytotoxic effects, though dental pulp exposed to lower concentrations is able to recover their viability when Bis-GMA is removed.
\end{abstract}

Key words: Apoptosis. Bis-GMA. Cell viability. Dental pulp.

\section{INTRODUCTION}

During restorative procedures for a carious tooth, dental pulp is exposed to a variety of stimulations such as heat stress produced by cavity preparation ${ }^{2}$, and hypoxia produced by local anesthesia ${ }^{1}$.

When composite resin is used as a restorative material, dentists sometimes note inflammatory responses of dental pulp, which are considered to be caused by microleakage at the interface between cavity walls and filled composite resin ${ }^{8,10}$. Other studies have suggested that unpolymerized resin monomers remaining on the cavity floor may irritate dental pulp cells directly or indirectly through dentin, resulting in inflammatory responses ${ }^{9,12}$.

It has previously been reported that apoptosis of pulp cells was induced during pulp wound healing after cavity preparation ${ }^{5}$, and that apoptosis of pulp cell line was induced by heat stress ${ }^{6}$ and hypoxia ${ }^{13}$. It was also found that capping agents modified pulp apoptosis induction?. Apoptotic cells induced in dental pulp disappear during pulp wound healing processes, suggesting cytotoxic effects of external stimulations via residual dentin and the recovery of dental pulp viability. However, it is largely unknown whether dental pulp cells adversely affected by resin monomers can recover their viability. In the present study, we examined effects of resin monomer, 2, 2-bis [4-(2-hydroxy-3-methacryloxypropoxy) phenyl] propane (Bis-GMA), on the viability of human dental pulp cell line. 


\section{MATERIAL AND METHODS}

\section{Cell culture}

LSC2 cells, a dental pulp cell line derived from human dental pulp ${ }^{11}$, were maintained in Dulbecco's modified Eagle's medium (DMEM; Invitrogen Corp., Carlsbad, CA, USA) containing 10\% heat-inactivated fetal calf serum (FCS), $100 \mu \mathrm{g} / \mathrm{mL}$ of streptomycin, and $100 \mathrm{U} / \mathrm{mL}$ of penicillin, and then incubated in a humidified atmosphere of $5 \% \mathrm{CO}_{2}$ at $37^{\circ} \mathrm{C}$.

\section{Cell proliferation assay}

LSC2 cells $\left(2 \times 10^{4}\right.$ cells/well) were cultured in 96 well plate with a medium containing $5 \%$ FCS for $24 \mathrm{~h}$, then the medium was exchanged to that containing $1 \%$ FCS. Several different concentrations $(0.01,0.02,0.03$, and $0.04 \mathrm{mmol} / \mathrm{L})$ of Bis-GMA (Polyscience Inc., Warrington, PA, USA) diluted by dimethylsulfoxide (DMSO; Wako Pure Chemical Inc, Osaka, Japan) were added to the culture medium. At $48 \mathrm{~h}$ after exposure to Bis-GMA, cell proliferation was examined using the 5-bromo-2'-deoxyuridine (BrdU) assay (The Biotrak cell proliferation ELISA system version 2; GE Healthcare UK Ltd, UK). Cell viability was analyzed by measuring optical density (OD) using a test wavelength of $540 \mathrm{~nm}$ and a reference wavelength of $620 \mathrm{~nm}$ with a multiscan biochromatic microplate reader (Multiscan JX; Thermo Fisher Scientific K.K., Yokohama, Japan).

\section{Cell cycle analysis}

LSC2 cells were exposed to Bis-GMA for 48 h, then suspended in a hypotonic solution $(0.1 \%$ Triton $\mathrm{X}-100,1 \mathrm{mmol} / \mathrm{L}$ Tris$/ \mathrm{HCl}, \mathrm{pH} 8.0,3.4 \mathrm{mmol} / \mathrm{L}$ sodium citrate, $0.1 \mathrm{mmol} / \mathrm{L}$ EDTA) and stained with $5 \mu \mathrm{g} / \mathrm{mL}$ of propidium iodide, after which cell-cycle distribution was analyzed with a FACScalibur flow cytometer EPICS XL (Beckman Coulter Inc., Brea, CA, USA).

\section{Detection of cell death by hoechst staining}

LSC2 cells were exposed to Bis-GMA in a chamber slides for $48 \mathrm{~h}$, then fixed with $1 \%$ glutaraldehyde for $30 \mathrm{~min}$, washed with $1 x$ phosphate buffered saline (PBS), and stained with $5 \mathrm{~g} / \mathrm{mL}$ of Hoechst dye 33342 (Life Technologies Co., CA, USA). Cells detached from the coverslips into the medium were also recovered by centrifugation and stained. Nuclei were observed under a fluorescence microscope (OLYMPUS BX50/BX-FLA/DP70; Olympus Co., Tokyo, Japan).

\section{Cell recovery after removal of Bis-GMA from culture medium}

After exposure of LSC2 cells to Bis-GMA for $48 \mathrm{~h}$, the wells were rinsed by PBS, and added a medium containing $10 \%$ FCS without Bis-GMA. After the culture of surviving cells in a humidified atmosphere of $5 \% \mathrm{CO}_{2}$ at $37^{\circ} \mathrm{C}$ for $96 \mathrm{~h}$, cell proliferation and cell cycle were analyzed.

\section{Dentin penetration assay}

Dentin discs ( $1 \mathrm{~mm}$ thick, minimum diameter: 6 $\mathrm{mm}$ ) were cut from freshly extracted sound human third molars using a low speed diamond-coated saw (Isomet; Buehler, Lake Bluff, IL, USA) under water coolant, then etched for $60 \mathrm{~s}$ with $35 \%$ phosphoric acid to completely open dentinal tubules, rinsed with ultrasonication for $3 \mathrm{~min}$ in distilled water, and placed in the PFA tube (Sanplatec, Osaka, Japan). The lower chamber was filled with distilled water and the upper chamber with $0.2 \mathrm{mmol} / \mathrm{L}$ of Bis-GMA. After standing in a humid chamber at room temperature for 2 weeks, the distilled water was collected and mixed with chloroform to isolate Bis-GMA. Bis-GMA was detected using isocratic high-performance liquid chromatography (HPLC) (Waters, Milford, MA, USA) with a reverse-phase column ( $\mu$-Bondashere C18, $5 \mu \mathrm{m}, 300$ A column, JLC010032Y) (Waters) at $280 \mathrm{~nm}$. The peak area

\section{A}

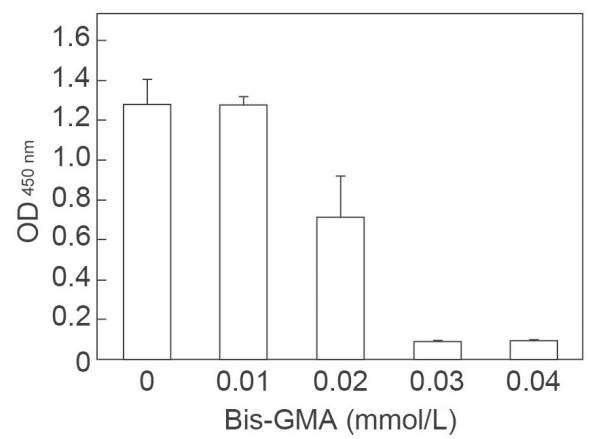

B
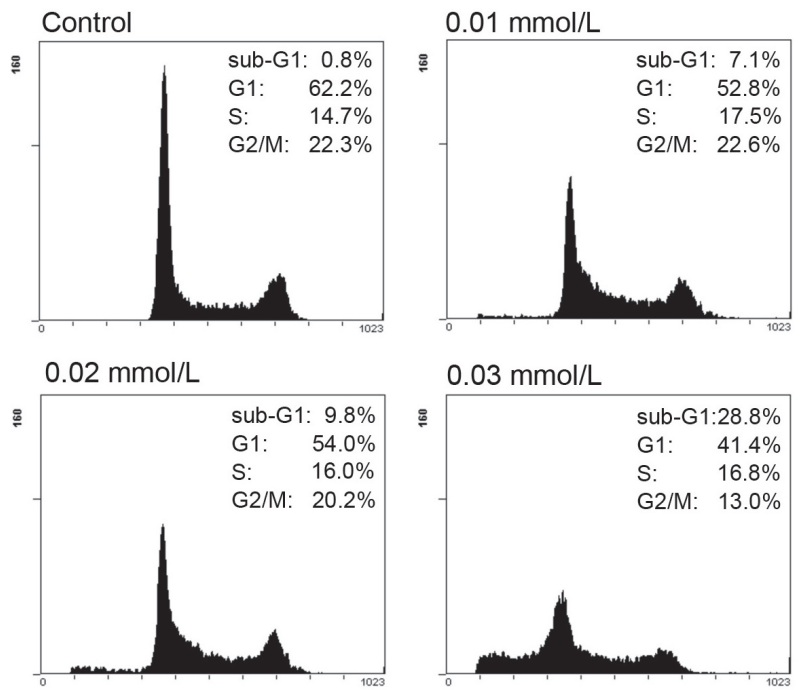

Figure 1- Cytotoxic effects of 2, 2-bis [4-(2-hydroxy-3methacryloxypropoxy) phenyl] propane (Bis-GMA) on LSC2 cells. (A). Viability of LSC2 cells after exposure to Bis-GMA. (B). Cell cycle of LSC2 cells after exposure to Bis-GMA 
A
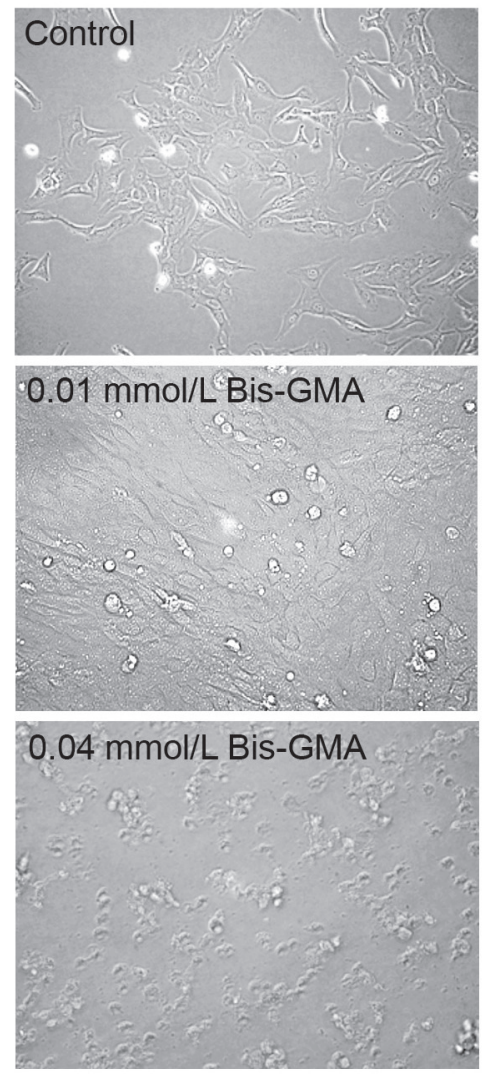

B
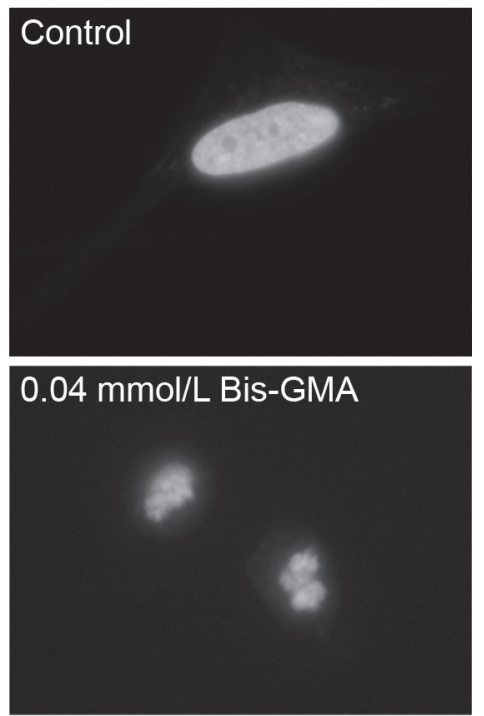

Figue 2- Morphological changes of LSC2 cells promoted by 2, 2-bis [4-(2-hydroxy-3-methacryloxypropoxy) phenyl] propane (Bis-GMA). (A). Phase-contrast microphotographs of LSC2 cells after exposure to Bis-GMA. Original magnification, x100. (B). Fluorescent microphotographs of LSC2 cells after exposure to Bis-GMA. Original magnification, $x 400$

of Bis-GMA shown by HPLC tracing was analyzed using the Waters 2487 Dual $\lambda$ absorbance detector (Waters), and the amount of Bis-GMA was calculated from the calibration curve of known concentrations from control experiments.

\section{Statistical analysis}

Statistical analysis of the data was performed using one-way ANOVA followed by a multiplecomparison Sheffe's test with Statview 5.0 software (SAS software Inc., Cary, NC, USA). Statistical significance was determined at $p<0.05$.

\section{RESULTS}

\section{Cell death of human dental pulp cells after exposure to Bis-GMA}

The viability of LSC2 cells decreased after exposure to Bis-GMA in a dose-dependent manner (Figure 1A). There was no significant difference $(p>0.05)$ in viability between 0 and $0.01 \mathrm{mmol} / \mathrm{L}$ of Bis-GMA, whereas significant decreases of cell viability were observed after being cultured with $0.02,0.03$, and $0.04 \mathrm{mmol} / \mathrm{L}$ of Bis-GMA $(p<0.01)$. The effects of exposure to Bis-GMA on cell cycle progression of LSC2 cells are shown in Figure 1B.
Exposure to Bis-GMA reduced the number of the cells in $\mathrm{G} 1, \mathrm{~S}$, and $\mathrm{G} 2 / \mathrm{M}$ phases in a dose-dependent manner, with a concomitant increase of those in the sub-G1 population, implying cell death such as apoptosis.

Morphological changes of LSC2 cells following exposure to Bis-GMA are shown in Figure 2. The structures of those cells exposed to $0.01 \mathrm{mmol} / \mathrm{L}$ of Bis-GMA were nearly the same as those of the control, whereas the rounding and the detachment were observed in cells exposed to $0.04 \mathrm{mmol} / \mathrm{L}$ of Bis-GMA (Figure 2A). Fluorescent microscopic analysis revealed that the nuclei of adhesive cells had normal structures, whereas those of cells that had fallen into the medium after exposure to 0.04 $\mathrm{mmol} / \mathrm{L}$ of Bis-GMA showed fragmentation, a typical characteristic of apoptotic cells (Figure 2B).

\section{Recovery of cell viability after the removal of Bis-GMA \\ Following exposure to Bis-GMA, surviving cells attached to the bottom of the well were cultured in normal condition without Bis-GMA (Figure 3A). The proliferation of surviving cells following exposure to 0.01 and $0.02 \mathrm{mmol} / \mathrm{L}$ of Bis-GMA was not different after $24 \mathrm{~h}$ of cell culture in normal condition, and}


A

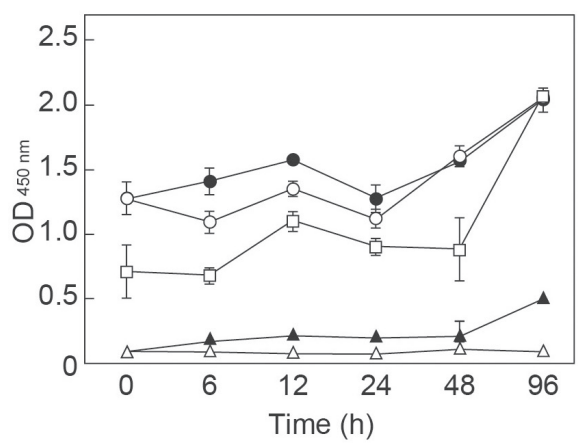

B
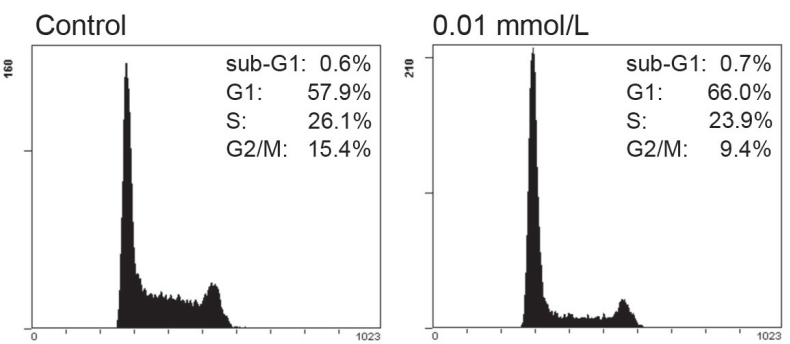

$0.02 \mathrm{mmol} / \mathrm{L}$

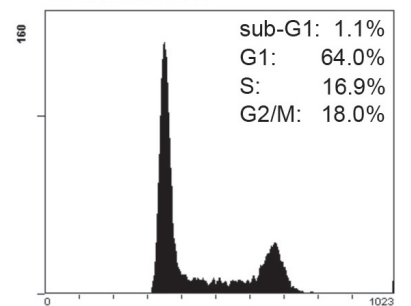

$0.03 \mathrm{mmol} / \mathrm{L}$

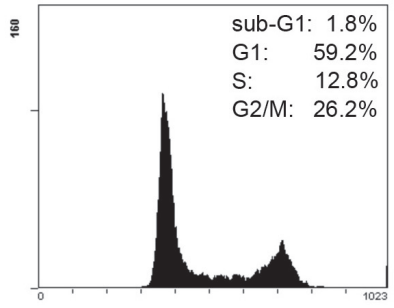

Figue 3- Survival of LSC2 cells against 2, 2-bis [4-(2-hydroxy-3-methacryloxypropoxy) phenyl] propane (Bis-GMA). (A). Recovery of viability of LSC2 cells that survived after exposure to Bis-GMA. Concentrations of Bis-GMA (mmol/L); 0 (black circle), 0.01 (white circle), 0.02 (white rectangle), 0.03 (black triangle), and 0.04 (white triangle). (B). Cell cycle of LSC2 cells that survived after exposure to Bis-GMA

then increased at 48 and $96 \mathrm{~h}$, while surviving cells exposed to $0.03 \mathrm{mmol} / \mathrm{L}$ of Bis-GMA showed proliferation at $96 \mathrm{~h}$. In contrast, exposure to 0.04 $\mathrm{mmol} / \mathrm{L}$ of Bis-GMA showed great cytotoxicity on the viability of the cells, and proliferation was not recovered during the culture in the normal condition. The recovery of cell-cycle progression in surviving cells exposed to $0.01,0.02$, and 0.03 $\mathrm{mmol} / \mathrm{L}$ of Bis-GMA was also observed (Figure 3B). When Bis-GMA-exposed cells were cultured in normal condition without Bis-GMA for $96 \mathrm{~h}$, the cell cycle distribution pattern of Bis-GMA-insulted cells returned to that prior to exposure to Bis-GMA.

\section{Dentin penetration of Bis-GMA through dentinal tubules}

In the penetration model, Bis-GMA penetrated through $1 \mathrm{~mm}$ thick dentin disc. From the calibration

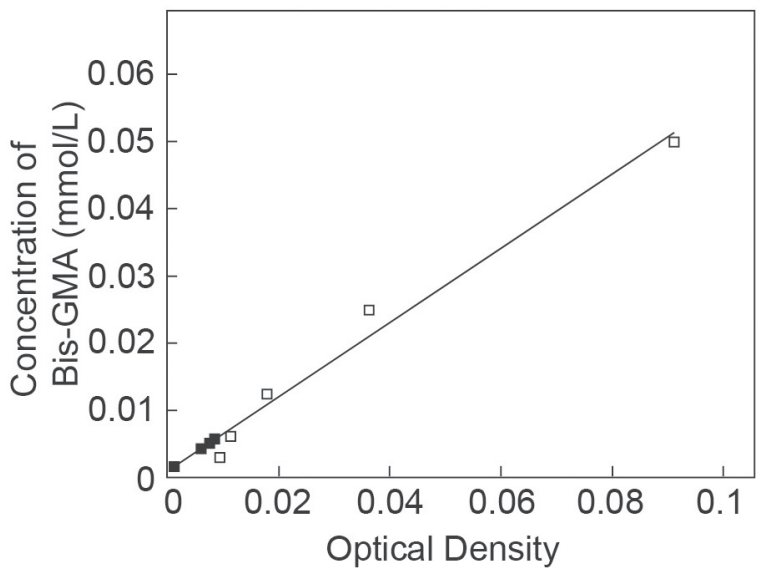

Figue 4- Calibration curve of known concentrations of 2, 2-bis [4-(2-hydroxy-3-methacryloxypropoxy) phenyl] propane (Bis-GMA) and concentrations of Bis-GMA that penetrated $1 \mathrm{~mm}$ dentin discs. White rectangles indicate known concentrations of control Bis-GMA for the calibration curve. Black rectangles indicate concentrations calculated from HPLC results of penetrated Bis-GMA

curve of known concentrations of Bis-GMA, the average concentration of penetrated Bis-GMA was $0.0043 \mathrm{mmol} / \mathrm{L}$ (Figure 4).

\section{DISCUSSION}

In the present study, it was found that exposure to high concentrations of Bis-GMA induced an increase in cell number in the sub-G1 population in cell-cycle, and the cell death with typical structures of apoptosis, suggesting that direct exposure to a high concentration of Bis-GMA induced apoptosis in human dental pulp cells.

It was also examined whether LSC2 cells exposed to Bis-GMA can recover their viability after the removal of Bis-GMA. We cultured surviving cells after exposure to Bis-GMA in the normal medium without Bis-GMA, and found that the cells exposed to $0.01,0,02$, and $0.03 \mathrm{mmol} / \mathrm{L}$ of Bis-GMA showed the recovery of the cell proliferation, whereas those exposed to $0.04 \mathrm{mmol} / \mathrm{L}$ of Bis-GMA did not recover their proliferation. In addition, cell-cycle of surviving cells after exposure to $0.01,0.02$, and $0.03 \mathrm{mmol} / \mathrm{L}$ of Bis-GMA returned to the same level as the control. These results suggest that even after the exposure to Bis-GMA, LSC2 cells have an ability to recover their viability when the concentration of Bis-GMA is low, whereas the cells exposed to high concentration of Bis-GMA lose such recovery ability.

Another finding of the present study was that the average concentration of Bis-GMA that penetrated $1 \mathrm{~mm}$ thick dentin was $0.0043 \mathrm{mmol} / \mathrm{L}$, which was lower than the concentration used in the present study. These results are consistent with previous studies $^{3,4}$, and suggest that an adequate volume of 
residual dentin thickness would be able to suppress the penetration of a harmful concentration of BisGMA.

Taken together, the findings of the present study suggest that dental pulp cells have the tolerance against lower concentrations of resin monomers, and that polymerized composite resin on the sufficient thickness of residual dentin may not be harmful to dental pulp.

\section{CONCLUSION}

These results produced evidence that Bis-GMA has cytotoxic effects, though dental pulp exposed to lower concentrations is able to recover their viability when Bis-GMA is removed.

\section{ACKNOWLEDGEMENTS}

This research was supported by Grants in Aid for Scientific Research 18209057 and 20592231 from The Ministry of Education, Science, and Culture of Japan, Tokyo, Japan.

\section{REFERENCES}

1- Agata H, Kagami H, Watanabe N, Ueda M. Effect of ischemic culture conditions on the survival and differentiation of porcine dental pulp-derived cells. Differentiation. 2008;76:981-93.

2- Amano T, Muramatsu T, Amemiya K, Kubo K, Shimono M. Responses of rat pulp cells to heat stress in vitro. J Dent Res. 2006;85:432-5.

3- Bouillaguet S, Wataha JC, Hanks CT, Ciucchi B, Holz J. In vitro cytotoxicity and dentin permeability of HEMA. J Endod. 1996;22:244-8.

4- Hanks CT, Wataha JC, Parsell RR, Strawn SE, Fat JC. Permeability of biological and synthetic molecules through dentine. J Oral Rehabil. 1994;21:475-87.

5- Kitamura C, Kimura K, Nakayama T, Toyoshima K, Terashita M. Primary and secondary induction of apoptosis in odontoblasts after cavity preparation of rat molars. J Dent Res. 2001;80:1530-4.

6- Kitamura C, Nishihara T, Ueno Y, Chen K-K, Morotomi T, Yano J, et al. Effects of sequential exposure to lipopolysaccharide and heat stress on dental pulp cells. J Cell Biochem. 2006;99:797-806. 7- Kitamura C, Ogawa Y, Morotomi T, Terashita M. Differential induction of apoptosis by capping agents during pulp wound healing. J Endod. 2003;29:41-3.

8- Lu Y, Liu T, Li H, Pi G. Histological evaluation of direct pulp capping with a self-etching adhesive and calcium hydroxide on human pulp tissue. Int Endod J. 2008;41:643-50.

9- Mantellini MG, Botero TM, Yaman P, Dennison JB, Hanks CT, Nör JE. Adhesive resin induces apoptosis and cell-cycle arrest of pulp cells. J Dent Res. 2003;82(8):592-6.

10- Murray PE, Smyth TW, About I, Remusat R, Franquin JC, Smith $A J$. The effect of etching on bacterial microleakage of an adhesive composite restoration. J Dent. 2002;30:29-36.

11- Rikitake Y. Immortalization of human dental pulp cells with transfecting of the plasmid, pMT1-neo. Kokubyo Gakkai Zasshi. 1989;56:540-61.

12- Schweikl H, Spagnuolo G, Schmalz G. Genetic and cellular toxicology of dental resin monomers. J Dent Res. 2006;85:870-7. 13- Ueno $Y$, Kitamura $C$, Terashita M, Nishihara T. Re-oxygenation improves hypoxia-induced pulp cell arrest. J Dent Res. 2006;85:824-8. 